\title{
International Trade, Food Security and the Response to the WTO in South Asian Countries
}

\author{
Ramesh Chand*
}

October 2006

\begin{abstract}
Agriculture contributes substantially to output and employment in South Asian countries. Therefore, any change, like trade liberalization, that impacts on the agriculture sector has widespread ramifications in terms of employment, nutrition, livelihood and food security. Implementation of various provisions of the WTO Agreement on Agriculture causes serious concern with regard to the performance of the agriculture sector and food security, and these countries have become quite sensitive to consequences of future WTO agreements. The cautious approach towards the WTO is mainly caused by the increased dependence on food imports and deterioration in self-reliance in agriculture in the post-WTO period because of a much higher growth in food import as compared to exports. Decline in international prices and trade distortions are the underlying causes for an adverse impact on agriculture during the post-WTO period. South Asian countries should address these two issues in future negotiations.
\end{abstract}

Keywords: trade liberalization, WTO, food security, imports, self-sufficiency, subsidies, OECD, agriculture, price volality

JEL classification: Q17, F13

Copyright @ C UNU-WIDER 2006

* National Centre for Agricultural Economics and Policy Research, New Delhi, email: rc@ncap.res.in

This paper was prepared for the UNU-WIDER project on Hunger and Food Security: New Challenges and New Opportunities, directed by Basudeb Guha-Khasnobis. The project was carried out in collaboration with the Indian Council of Social Science Research (ICSSR) and the UN Food and Agriculture Organization (FAO).

UNU-WIDER gratefully acknowledges the financial contributions to its research programme by the governments of Denmark (Royal Ministry of Foreign Affairs), Finland (Ministry for Foreign Affairs), Norway (Royal Ministry of Foreign Affairs), Sweden (Swedish International Development Cooperation Agency_Sida) and the United Kingdom (Department for International Development).

ISSN 1810-2611 ISBN 92-9190-908-4 (internet version) 


\section{Acronyms}

AMS aggregate measure of support

AoA Agreement on Agriculture (of the World Trade Organization)

CWE Cooperative Wholesale Establishment

EU European Union

FCI Food Corporation of India

GDP gross domestic product

OECD Organization for Economic Cooperation and Development

QRs quantitative restrictions

SACs South Asian countries

S\&D $\quad$ special and differential treatment

SPS Sanitary and phytosanitary measures

STEs state trading enterprises

UR Uruguay Round

WTO World Trade Organization

The World Institute for Development Economics Research (WIDER) was established by the United Nations University (UNU) as its first research and training centre and started work in Helsinki, Finland in 1985. The Institute undertakes applied research and policy analysis on structural changes affecting the developing and transitional economies, provides a forum for the advocacy of policies leading to robust, equitable and environmentally sustainable growth, and promotes capacity strengthening and training in the field of economic and social policy making. Work is carried out by staff researchers and visiting scholars in Helsinki and through networks of collaborating scholars and institutions around the world.

www.wider.unu.edu

publications@wider.unu.edu

UNU World Institute for Development Economics Research (UNU-WIDER)

Katajanokanlaituri 6 B, 00160 Helsinki, Finland

Camera-ready typescript prepared by Liisa Roponen at UNU-WIDER

The views expressed in this publication are those of the author(s). Publication does not imply endorsement by the Institute or the United Nations University, nor by the programme/project sponsors, of any of the views expressed. 


\section{Introduction}

Agriculture is the mainstay of the South Asian economies. About 20-41 per cent of national output and 44 to 73 per cent employment are contributed by this sector in various countries in the region. Heavy dependence on agriculture, low productivity, low growth rate of economy and slow growth in employment opportunities in nonagriculture sector are the salient features of South Asian countries (SACs) and are largely responsible for widespread poverty and undernutrition in the region. As would be seen from Table 1, more than 30 per cent of the rural population in India, 36 per cent in Pakistan, 44 per cent in Nepal and more than 50 per cent in Bangladesh live under poverty. Similarly, the incidence of undernutrition varies from 17 per cent in Nepal to 32 per cent in Bangladesh. Any adverse impact on agriculture sector in these countries, from forces like trade liberalization, has widespread ramifications in terms of employment, nutrition, livelihood, and food security.

Historically, SACs have followed inward-looking trade policies. Sri Lanka was the first country in the region to undertake trade reforms. It initiated liberalization in the late 1970s. Other countries initiated serious trade liberalization policies during early 1990s primarily in nonagriculture sector. Reforms in agriculture trade were missing, or were quite slow until the Uruguay Round of GATT, which was implemented in 1995 with the establishment of the World Trade Organization (WTO). The Uruguay Round (UR) requires adjustments in domestic policies involving greater importance to trade rather than supporting self-sufficiency to achieve or maintain food security. This is a serious concern to SACs as food security has remained the chief concern of development policy of these countries and they have striven hard to attain this goal by improving or acquiring self sufficiency in foodgrain. Though these countries sometimes faced situations of availability of cheap foodgrain in the international markets, it was considered highly desirable to develop domestic capability, as trade was not considered as a reliable source to meet the needs of principal food items of domestic population.

Table 1

Agro-economic profile of the SACs

\begin{tabular}{llrrrrr}
\hline Particular & Ref. year & Bangladesh & India & Nepal & Pakistan & Sri Lanka \\
\hline Per capita gross national income \$ & 2002 & 380 & 495 & 230 & 420 & 850 \\
Income rank in the world & 2002 & 171 & 161 & 191 & 168 & 142 \\
Arable land: ha per capita & $1999-01$ & 0.06 & 0.16 & 0.13 & 0.15 & 0.05 \\
Share of agriculture in GDP \% & 2002 & 23 & 23 & 41 & 23 & 20 \\
Workforce in agriculture & Around 2000 & & & & & \\
Male & & 53 & 58.4 & NA & 44 & 49 \\
Female & & 77 & $($ Total) & NA & 73 & 38 \\
Agriculture value added/worker 1995 \$2000-02 & 318 & 401 & 203 & 716 & 725 \\
Population under poverty \% & Late 1990s & & & & & \\
Rural & & 53.0 & 30.2 & 44.0 & 35.9 & 27.0 \\
Urban & & 36.8 & 24.7 & 23.0 & 24.2 & 15.0 \\
Undernourished population \% & 2001 & 32 & 21 & 17 & 19 & 25 \\
\hline
\end{tabular}

Source: World Bank (2004). 
This paper analyses the changes in agricultural trade, changes in the dependence on food imports, trade orientation of agriculture, agricultural growth in SACs before and after WTO, and food security issues related to trade liberalization. Based on the experience with implementation of UR, the paper discusses issues of concern to the SACs for negotiations in the next round of WTO agreement. This analysis is based on the data covering the period from 1991 to 2002. The whole period was studied by taking four yearly averages of trade data, terming 1991-94 as before WTO, 1995-1998 as the launching or initial years of WTO and 1999-2002 as post-WTO.

\section{Agriculture trade before and after WTO}

A general idea about the impact of UR on the agriculture trade of the SACs can be obtained by looking at agricultural trade before and after 1995 when the WTO Agreement came into effect. Basic information on SAC trade before and after WTO is provided in Table 2.

Agricultural exports of Bangladesh increased from US\$128 million in the four years before WTO to US\$139 million in the initial years of implementation of Agreement on Agriculture (AoA). The post-WTO period (1999-2002) saw a sharp fall in exports. On the other hand, agricultural imports increased from US\$1.248 billion to US\$1.623 billion since the implementation of WTO. The net result has been that trade deficit of Bangladesh rose by more than 38 per cent with the implementation of AoA.

In the case of India, agricultural exports as well as imports followed a substantial increase in the initial years of WTO. India's trade surplus, which increased from US\$1.7 billion in

Table 2

Agriculture trade of SACs before and after WTO, US\$ million

\begin{tabular}{|c|c|c|c|}
\hline Country & 1991-94: Before WTO & 1995-98: Start of WTO & 1999-2002: After WTO \\
\hline \multicolumn{4}{|l|}{ Bangladesh } \\
\hline Exports & 128 & 139 & 105 \\
\hline Imports & 663 & 1248 & 1623 \\
\hline Net trade & -535 & -1109 & -1518 \\
\hline \multicolumn{4}{|l|}{ India } \\
\hline Exports & 3085 & 5557 & 5087 \\
\hline Imports & 1336 & 2711 & 3699 \\
\hline Net trade & 1749 & 2846 & 1388 \\
\hline \multicolumn{4}{|l|}{ Nepal } \\
\hline Exports & 49 & 48 & 58 \\
\hline Imports & 141 & 217 & 194 \\
\hline Net trade & -92 & -169 & -136 \\
\hline \multicolumn{4}{|l|}{ Pakistan } \\
\hline Exports & 956 & 1101 & 1067 \\
\hline Imports & 1405 & 2135 & 1814 \\
\hline Net trade & -448 & -1034 & -747 \\
\hline \multicolumn{4}{|l|}{ Sri Lanka } \\
\hline Exports & 528 & 923 & 969 \\
\hline Imports & 500 & 779 & 766 \\
\hline Net trade & 29 & 144 & 202 \\
\hline
\end{tabular}

Source: Calculated by author from the FAOSTAT Database. 
the early 1990s to US $\$ 2.8$ billion by 1998 , dropped to US $\$ 1.388$ billion in the post-WTO period. Thus, India also witnessed almost a similar impact from WTO on agricultural trade as was experienced by Bangladesh.

The agricultural trade of Nepal shows a substantial increase in imports and a trade deficit in the initial years of WTO. Although there was some decline in imports and the trade deficit in the later years, these remained higher than in the pre-WTO years.

Agricultural exports of Pakistan, as in India and Bangladesh, tuned out to be lower in the post-WTO period. However, its imports behaved differently as they declined from US\$2.135 billion in the beginning of WTO to US\$1.814 billion after WTO. This helped Pakistan to reduce its worsening trade deficit that had reached more than 1 billion dollars with the implementation of WTO agreement.

Agricultural exports of Sri Lanka were only slightly higher than its imports during 199194. The situation turned favourable for exports after 1995 and resulted in a large trade surplus. There was further improvement in the trade surplus of agriculture during post-WTO period.

Based on the above analysis, the summary impact of WTO AoA trade of SACs is generalized in Table 3.

Table 3

Summary indicators of impact of WTO on agricultural trade of SACs

\begin{tabular}{llll}
\hline Country & Impact on imports & Impact on exports & Net impact \\
\hline Bangladesh & Highly adverse & Highly Adverse & Highly adverse \\
India & Highly adverse & Favourable & Adverse \\
Pakistan & Adverse & Slightly favourable & Adverse \\
Sri Lanka & Adverse & Favourable & Favourable \\
Nepal & Adverse & Favourable & Adverse \\
\hline
\end{tabular}

Source: Calculated by the author based on Table 2 .

\subsection{Composition of trade}

Major items of exports and imports and changes in their trading volume during 1991 to 2002 in the five SACs are presented in Table 4.

\section{Bangladesh}

Wheat, vegetable oil, oilseeds, cotton and rice are the major items of farm imports for Bangladesh. There was a substantial increase in the import of these items at the beginning of WTO and the increase continued at a moderate rate in the post-WTO period. The biggest increase took place in the case of rice whose imports increased from US\$5.6 million before WTO to US\$186.7 million in the initial years of WTO. Wheat emerged as the largest import item, followed by soybean oil. Bangladesh's import of vegetable oil moved close to 100 thousand tons and constituted 30 per cent of its total agricultural imports in value term. In addition, more than US\$100 million is spent on oilseeds and oilcake. Oilcake has emerged as a new import item in recent years. 
Bangladesh has a very small volume of agricultural exports, which is less than one-tenth of its imports. Exports of fruit and vegetables showed promising growth with the start of WTO but then stagnated to around US\$12 million. The export of tea halved in the post-WTO period and jute exports dropped by about 16 per cent.

\section{India}

Vegetable oil, cotton, and pulses are the major items of India's agricultural imports. In the last ten years, import of vegetable oils and cotton has seen an amazing increase more than tenfold. Import bill for vegetable oil was US\$130 million in early 1990s, i.e., before WTO, but increased to US\$1632 million in the late 1990s (Table 4: Panel B). India's imports volume has exceeded 1 million tons of soybean oil and three million tons of palm oil. The imports of cotton and pulses have reached US\$315 million and US\$387 million, respectively.

During 1991 to 2002, the export of rice, fruit and vegetables has seen substantial growth. In the case of rice, a major boost to exports came from the domestic front in the removal of restrictions on the export of non-basmati rice. Rice exports crossed \$1 billion mark with the beginning of WTO. The later years of WTO membership turned out to be unfavourable for rice exports. In contrast, the exports of fruit and vegetables and cashew nuts have seen a smooth and steady growth, indicating the favourable impact of WTO.

Exports of oilcake, which was the most important item of agricultural exports during early 1990s, has received serious setback in the post-WTO period. Coffee exports more than doubled in the beginning years of WTO compared to the quadrennium before 1995 but then faced very sharp decline. Tobacco and spices were big beneficiaries of liberalization but in the later years their export either stagnated or showed sluggish growth. India also exports some oilseeds and their export has risen steadily and reached close to US\$200 million in the quadrennium ending 2002 as against US\$66 million before WTO. Exports of cotton have almost dried up and India has become a large importer of the commodity. Exports of sugar have had a rising trend.

\section{Pakistan}

Pakistan witnessed a substantial increase in imports of fruit and vegetables, pulses, cotton and oilseeds and sharp fluctuations in imports of wheat, sugar and vegetable oils (Table 4: Panel C). Cotton crop was badly affected even before WTO as its exports declined from more than US\$322 million in early the 1990 s to US\$167 million by the quadrennium ending 1998, and imports increased from US\$24 million to more than US\$154 million. In the post-WTO period, imports increased further and exports declined sharply.

In recent years, Pakistan has succeeded in reducing its dependence on import of wheat and edible oil. A closer look at vegetable oil imports shows that this decrease is purely due to a decline in price, and the quantity of imports has remained almost the same. As is the case with India, the export of horticultural crops moved on a steadily rising trend. Rice exports remained above US\$500 million after the early 1990s. Sugar exports show large swings. 
Table 4

Changes in major agricultural exports and imports for selected SACs, 1991 to 2002, US\$ million per year

\begin{tabular}{|c|c|c|c|c|}
\hline \multicolumn{2}{|l|}{ Trade } & 1991-94 & 1994-98 & $1999-2002$ \\
\hline & & \multicolumn{3}{|c|}{ Panel A: BANGLADESH } \\
\hline \multirow[t]{10}{*}{ Imports: } & Cotton lint & 89.8 & 167.6 & 197.9 \\
\hline & Rice & 5.6 & 186.7 & 193.4 \\
\hline & Sugar (raw equivalent) & 18.2 & 40.2 & 66.1 \\
\hline & Wheat and flour, wheat equiv. & 164.2 & 185.5 & 259.5 \\
\hline & Dairy products and eggs & 69.0 & 58.0 & 84.5 \\
\hline & Fixed vegetable oils & 137.7 & 293.8 & 391.7 \\
\hline & Palm oil & 37.4 & 70.3 & 109.6 \\
\hline & Soybean oil & 94.6 & 217.1 & 273.8 \\
\hline & Oilseed cake meal & 0.1 & 1.7 & 19.1 \\
\hline & Oilseeds & 47.8 & 91.1 & 83.9 \\
\hline \multirow[t]{4}{*}{ Exports: } & Fruit and vegetables & 5.9 & 11.3 & 12.1 \\
\hline & Jute & 75.2 & 82.4 & 69.2 \\
\hline & Tea & 39.7 & 35.0 & 16.6 \\
\hline & & \multicolumn{3}{|c|}{ Panel B: INDIA } \\
\hline \multirow[t]{5}{*}{ Imports: } & Cotton lint & 63.2 & 70.5 & 314.8 \\
\hline & Fixed vegetable oils & 129.9 & 1047.2 & 1632.2 \\
\hline & Palm oil & 85.8 & 732.1 & 1045.9 \\
\hline & Soybeans oil & 28.3 & 105.0 & 382.9 \\
\hline & Pulses & 159.4 & 254.8 & 386.9 \\
\hline \multirow[t]{12}{*}{ Exports: } & Rice & 369.5 & 1180.5 & 825.2 \\
\hline & Sugar (raw equivalent) & 63.5 & 106.9 & 211.5 \\
\hline & Cotton lint & 108.9 & 174.4 & 10.2 \\
\hline & Fruit and vegetables & 536.2 & 704.7 & 929.2 \\
\hline & Tea & 372.9 & 414.3 & 382.9 \\
\hline & Coffee & 194 & 430 & 256 \\
\hline & Oilseed cake meal & 571.1 & 775.4 & 411.6 \\
\hline & Oilseeds & 65.6 & 181.9 & 198.2 \\
\hline & Spices & 166 & 336 & 352 \\
\hline & Tobacco & 136 & 204 & 200 \\
\hline & Cashew nuts & 308 & 374 & 452 \\
\hline & & \multicolumn{3}{|c|}{ Panel C: PAKISTAN } \\
\hline \multirow[t]{11}{*}{ Imports: } & Fruit and vegetables & 94.0 & 139.7 & 198.6 \\
\hline & Pulses & 55.6 & 71.9 & 109.3 \\
\hline & Sugar (raw equivalent.) & 60.2 & 31.8 & 138.7 \\
\hline & Wheat and flour, wheat equiv. & 297.2 & 432.1 & 160.1 \\
\hline & Cotton lint & 24.4 & 154.1 & 182.1 \\
\hline & Fixed vegetable oils & 474.3 & 864.6 & 528.4 \\
\hline & Palm oil & 354.0 & 702.4 & 410.9 \\
\hline & Soybean oil & 114.4 & 145.2 & 87.7 \\
\hline & Tea & 182.8 & 185.6 & 201.8 \\
\hline & Oilseed cake meal & 0.1 & 11.7 & 20.8 \\
\hline & Oilseeds & 19.7 & 36.0 & 124.2 \\
\hline \multirow[t]{5}{*}{ Exports: } & Cotton lint & 322.0 & 167.3 & 59.8 \\
\hline & Fruit and vegetables & 58.0 & 80.1 & 119.9 \\
\hline & Rice & 329.8 & 506.1 & 526.4 \\
\hline & Sugar (raw equivalent) & 9.9 & 85.9 & 65.8 \\
\hline & Oilseeds & 14.9 & 14.8 & 15.5 \\
\hline
\end{tabular}


Table 4 (con't)

Changes in major agricultural exports and imports for selected SACs,

1991 to 2002, million \$ per year

\begin{tabular}{|c|c|c|c|}
\hline Trade & 1991-94 & 1994-98 & 1999-2002 \\
\hline & \multicolumn{3}{|c|}{ Panel D: NEPAL } \\
\hline Imports: Fruit and vegetables & 11.4 & 61.8 & 27.2 \\
\hline Fixed vegetable oils & 24.4 & 41.5 & 33.1 \\
\hline Palm oil & 7.7 & 8.0 & 20.7 \\
\hline Soybean oil & 14.5 & 8.9 & 7.7 \\
\hline Rice & 6.0 & 8.1 & 15.0 \\
\hline Sugar, total (raw equiv.) & 5.2 & 5.8 & 7.9 \\
\hline Oilseeds & 2.6 & 2.6 & 18.2 \\
\hline Exports: Butter & 0.5 & 0.6 & 3.1 \\
\hline Fruit and vegetables & 21.4 & 13.9 & 15.2 \\
\hline Pulses & 15.8 & 13.8 & 14.1 \\
\hline Oilseed cake meal & 2.1 & 1.8 & 2.8 \\
\hline \multirow[t]{2}{*}{ Oilseeds } & 6.1 & 9.0 & 0.9 \\
\hline & \multicolumn{3}{|c|}{ Panel E: SRI LANKA } \\
\hline Imports: Milk equivalent & 55.7 & 95.2 & 111.8 \\
\hline Rice & 38.9 & 46.5 & 19.7 \\
\hline Fixed vegetable oils & 18.2 & 37.8 & 42.1 \\
\hline Pulses & 30.0 & 47.4 & 53.0 \\
\hline Sugar (raw equiv.) & 102.5 & 141.9 & 127.1 \\
\hline Wheat and flour, wheat equiv. & 115.5 & 146.3 & 123.1 \\
\hline Oilseed cake meal & 7.4 & 12.7 & 16.2 \\
\hline Oilseeds & 1.8 & 1.5 & 4.2 \\
\hline Exports: Fruit and vegetables & 56.0 & 86.7 & 83.5 \\
\hline Rubber natural dry & 51.1 & 72.7 & 27.2 \\
\hline Tea & 308.4 & 594.6 & 654.9 \\
\hline Oilseeds & 3.9 & 6.2 & 8.3 \\
\hline
\end{tabular}

Source: Calculated by author from the FAOSTAT Database.

\section{Nepal}

Nepal's imports of major agricultural products, mainly fruit/vegetables and vegetable oil show substantial increases in the beginning of the WTO-years, after which there was a large decline. Rice imports have almost doubled in the post-WTO period while oilseeds imports increased sevenfold. The import of palm oil more than doubled whereas soybean oil shows a small decline. Sugar imports show a steady increase during the entire period after 1991 (Table 4: Panel D). Fruit and vegetable remained the largest export items, followed by pulses. In both cases, exports show a decline with the beginning of WTO but some recovery thereafter.

\section{Sri Lanka}

Sri Lanka spent more than US\$100 million on the import of sugar and wheat in the early 1990s (Table 4: Panel E). Their imports went up with the beginning of WTO, then decreasing slightly. A similar trend is observed in the case of pulses and rice. The imports of milk and related products, pulses and oilseed cake saw significant increases in the initial years of WTO, followed by a slow increase in the post-WTO period.

Tea alone accounts for more than two-thirds of Sri Lankan agricultural exports, which almost doubled with the beginning of WTO. Exports continued to increase in later 
years, but at a slower rate. Rubber exports received a serious setback in the post-WTO period while on fruit and vegetable there was a small adverse impact.

\subsection{Trade orientation of agriculture}

Ratio of imports and exports and total trade to agricultural GDP increased considerably in the beginning years of WTO. In the latter years (i.e., 1999 to 2002) the share of trade showed marginal increase in India, small decline in Bangladesh and sharp decline in Nepal, Pakistan and Sri Lanka.

Table 5

Share (\%) of trade in GDP agriculture of SACs

\begin{tabular}{llcrr}
\hline Country & Trade & $1991-94$ & $1995-98$ & $1999-2002$ \\
\hline India & Imports & 1.7 & 2.8 & 3.7 \\
& Exports & 3.9 & 5.7 & 5.2 \\
Bangladesh & Total trade & 5.6 & 8.4 & 8.9 \\
& Imports & 7.8 & 13.2 & 12.9 \\
& Exports & 1.5 & 1.5 & 0.8 \\
Nepal & Total trade & 9.3 & 14.6 & 13.7 \\
& Imports & 9.1 & 12.7 & 8.8 \\
& Exports & 3.2 & 2.8 & 2.9 \\
Pakistan & Total trade & 12.3 & 15.5 & 11.7 \\
& Imports & 13.7 & 15.9 & 10.8 \\
& Exports & 9.3 & 8.2 & 7.1 \\
Sri Lanka & Total trade & 23.1 & 24.0 & 17.9 \\
& Imports & 25.1 & 29.5 & 26.8 \\
& Exports & 26.5 & 34.9 & 30.3 \\
\hline
\end{tabular}

Source: Calculated by author from the FAOSTAT Database, and ADB (various issues).

\section{Trade liberalization and food security}

The relationship between food security and trade is quite complex and hardly uniform across countries. This relationship is determined by the choice of domestic policies and their effectiveness, production opportunities, infrastructure for commodity trade and exchange, comparative advantages and purchasing power of the people. It is because of this complexity of the relationship between trade and food security that there is no consensus in the literature on the impact of trade liberalization on food security. According to one school of thought, food self-sufficiency is essential for the food security of low-income countries as volatility in international prices can render them out of the reach of common people with small wages. This may not necessarily be the case for high-income people who have deep pockets. According to this view, temporary phase of low international prices should not be taken as a permanent opportunity and domestic capabilities of food production should be safeguarded in such times (Chand 2002).

It is also pointed out that a significant proportion of the population in SACs are not only dependent on agriculture for their livelihood, but also for survival in circumstances just around the poverty line. Therefore, it has been proposed that non-trade concerns such as 
maintenance of the livelihood of agrarian peasantry and the production of sufficient food to meet domestic needs are taken into consideration.

According to an alternative view, national self-sufficiency should not be confused with food security. It is believed that national self-sufficiency is neither necessary nor sufficient to guarantee food security at the individual level. In this context, the example of India is quite apt. Even though the country had 30 per cent of its grain production (more that 60 million tons) in public stock by the year 2000, every fourth Indian was reported to be undernourished and food insecure. This implies that entitlement and prices are very critical to food security.

According to this alternative stand, what a country needs is sufficient capacity to generate foreign exchange by specializing in goods based on the country's comparative advantage and importing what cannot be covered by domestic production (Panagariya 2002).

According to the first school of thought, an increase in imports to meet domestic demand adversely affects food self-sufficiency and, in turn, food security. According to the alternative view, imports should not be seen as having adverse impact on food security if they do not cause adverse effect on self reliance. The following section examines the impact of trade liberalization both on food self-sufficiency and self-reliance and then draws some inferences about impact of trade liberalization on food security.

\subsection{Impact on self sufficiency}

The impact on food self-sufficiency in the various SACs can be seen from the share of imports in domestic consumption. These estimates for major food commodities are given in Table 6 and for whole of food sector in Table 7.

India's reliance on imports to meet domestic demand for cereals, fruit, vegetables, and milk remained quite low, less than 1 per cent of demand during the 12-year period between 1991 and 2002. With the beginning of WTO-tenure, fruit imports started to increase and gained momentum over time but have remained below 1 per cent of total fruit intake. Dependence on sugar imports to meet domestic demand declined to less than 1.5 per cent with the implementation of WTO AoA.

The dependence on imports increased sharply for pulses, doubling in the last 12 years, and very heavily for vegetable oil. More than 10 per cent of pulses consumed in India are now imported. Imports met less than 6 per cent of vegetable oil used for food before WTO. This increased to 24 per cent in the initial years of WTO and is now approaching half of the total vegetable oil demand in India, forcing the country to import more than four million tons to meet domestic demand. With liberalization there has been small increase in fish imports but still remaining below 2.5 per cent.

Pakistan witnessed a decline in import dependence for cereals from more than 10 per cent prior to 1998 to 5.4 per cent in the post-WTO period. Reliance on imported vegetable oil also declined but is still very high, above 88 per cent. Between the quadrennium 1991 to 1994 and 1998 to 2002, the share of imported food items in domestic consumption increased from 6 per cent to 12 per cent for sugar, 23 per cent to 
36 per cent for pulses, 1.3 per cent to 3.9 percent for fruit and for vegetables from less than 1 per cent to more than 2.5 per cent.

Sri Lanka's import dependence indicates a tremendous increase for all food products except cereals, for which import reliance initially increased with the beginning of WTO but then dropped back to the level of the early 1990s. Imported cereals constitute more than 40 per cent of cereal consumption. The country's almost entire demand for sugar, 64 per cent of the milk demand, and 20 per cent of the vegetable demand are met from imports. the import of vegetable oils is double the level of consumption, perhaps a reflection of the fact some vegetable oil is used for industrial purposes and some is diverted to India via Sri Lanka, as Sri Lanka has much lower tariff than India and the free trade pact between the two countries is favourable for such trade deflection.

Nepal was not a member of WTO during the period under review, but has been affected by changes in agriculture brought about by WTO and globalization, particularly in its neighbouring country, India, which accounts for a overwhelming share of Nepal's trade. Highest share of imported items in food intake is for vegetable oil which has increased from 58 per cent in the early 1990s to 89 per cent in the post-WTO period. Sugar is another food item whose import dependence is quite high (29.4 per cent). Reliance on imported cereals and fruit indicates a rising trend, though around 2 per cent, it is low. For other products, imports witnessed a decline with the implementation of WTO but increased during the post-WTO period.

Table 6

The dependence of selected SACs on imports for food (\%)

\begin{tabular}{|c|c|c|c|c|c|c|c|c|c|c|c|}
\hline Country & 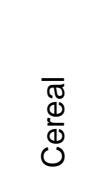 & $\begin{array}{l}\frac{\pi}{\mathbb{N}} \\
\stackrel{\infty}{3}\end{array}$ & $\frac{d}{\mathscr{U}}$ & 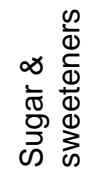 & $\begin{array}{l}\mathscr{N} \\
\stackrel{\mathscr{N}}{二} \\
\underline{\alpha}\end{array}$ & $\begin{array}{l}\frac{0}{0} \\
\frac{\pi}{0} \\
\stackrel{D}{D} \frac{n}{\circ}\end{array}$ & $\begin{array}{l}\frac{0}{0} \\
\frac{0}{0} \\
\frac{0}{0} \\
\frac{0}{3}\end{array}$ & 党 & $\stackrel{\mathbb{\pi}}{\mathbb{J}}^{\stackrel{\pi}{\Sigma}}$ & 妾 & 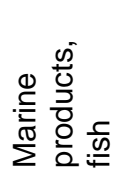 \\
\hline \multicolumn{12}{|l|}{ India } \\
\hline 1991-94 & 0.37 & 0.81 & 0.17 & 2.33 & 4.45 & 5.73 & 0.01 & 0.35 & 0.01 & 0.06 & 0.04 \\
\hline $1995-98$ & 0.67 & 1.73 & 0.05 & 1.64 & 6.08 & 24.39 & 0.01 & 0.61 & 0.00 & 0.04 & 2.40 \\
\hline 1999-2002 & 0.30 & 0.59 & 0.05 & 1.38 & 10.66 & 47.89 & 0.08 & 0.74 & 0.00 & 0.08 & 1.38 \\
\hline \multicolumn{12}{|l|}{ Pakistan } \\
\hline 1991-94 & 11.02 & 13.04 & 0.17 & 6.03 & 22.65 & 98.04 & 0.84 & 1.34 & 0.00 & 0.71 & 0.00 \\
\hline $1995-98$ & 11.99 & 14.34 & 0.05 & 6.25 & 20.86 & 95.40 & 2.00 & 2.08 & 0.01 & 0.52 & 0.00 \\
\hline 1999-2002 & 5.39 & 6.44 & 0.33 & 12.86 & 36.37 & 88.40 & 2.55 & 3.19 & 0.01 & 0.36 & 0.00 \\
\hline \multicolumn{12}{|l|}{ Sri Lanka } \\
\hline $1991-94$ & 40.51 & 100.78 & 9.00 & 76.03 & 60.23 & 101.39 & 10.52 & 1.60 & 1.04 & 49.24 & 0.01 \\
\hline 1995-98 & 47.18 & 104.67 & 11.44 & 89.13 & 79.41 & 166.15 & 17.32 & 3.47 & 1.89 & 57.88 & 0.00 \\
\hline 1999-2002 & 41.65 & 102.98 & 5.13 & 98.88 & 94.32 & 199.13 & 21.20 & 6.87 & 2.17 & 64.29 & 0.01 \\
\hline \multicolumn{12}{|l|}{ Nepal } \\
\hline $1991-94$ & 1.15 & 1.25 & 1.90 & 26.68 & 11.79 & 58.13 & 0.19 & 0.96 & 0.00 & 1.65 & 100.00 \\
\hline 1995-98 & 1.19 & 0.66 & 1.97 & 23.71 & 4.29 & 62.16 & 2.57 & 1.07 & 0.00 & 0.17 & 100.00 \\
\hline 1999-2002 & 2.21 & 1.27 & 3.27 & 29.37 & 11.17 & 89.49 & 0.42 & 1.88 & 0.05 & 1.41 & 100.00 \\
\hline \multicolumn{12}{|l|}{ Bangladesh } \\
\hline 1991-94 & 6.26 & 54.57 & 0.17 & 7.30 & 12.10 & 70.50 & 5.90 & 2.38 & 0.19 & 16.35 & 0.18 \\
\hline 1995-98 & 9.96 & 48.60 & 4.43 & 15.25 & 8.10 & 95.59 & 2.87 & 6.75 & 0.21 & 11.65 & 0.54 \\
\hline 1999-2002 & 12.55 & 62.36 & 4.04 & 32.98 & 25.00 & 120.49 & 3.77 & 8.61 & 0.06 & 18.31 & 19.97 \\
\hline
\end{tabular}

Source: Calculated by author based on data from the FAOSTAT Database. 
Table 6 shows a considerable increase for Bangladesh in imports for most food products after the early 1990s. Share of imported food items in domestic consumption increased from 6.2 per cent before WTO to 10 per cent in the initial years of WTO. This dependency increased further to 12.55 per cent in the post-WTO years. The share of imports in sugar consumption has more than doubled every four years. Similarly, the dependence on imported pulses has doubled from 12.1 per cent before WTO to more than 25 per cent in the post-WTO period. Imports of vegetable oil were as high as 70 per cent of domestic demand during 1991 to 1994, increasing after mid-1995 to 95.6 per cent. Currently vegetable oil imports are 20 per cent higher than consumption. The country has also seen an increased import content in the domestic demand for fruit, milk and marine products.

There were concerns that trade liberalization would result in increased dependence on food import. Actual experience shows that in all SACs the reliance on imports has increased very sharply for vegetable oil, and almost half of all requirement is met through imports. Even high tariff rates could not deter the import increase. The reason is that price of palm oil is very low compared to vegetable oils produced in SACs. Though other vegetable oils are considered to be of better quality, the general populations have attached greater weight to price than quality. Dependence on imports has also increased for pulses in all SACs except Nepal. The results vary across countries for other commodities. India has guarded effectively against the import of cereals, fruit and dairy products in the post-WTO period by with high tariffs, or in some instances, non-tariff measures. Pakistan and Sri Lanka could manage the same only in the case of cereals, and thus experienced increased import dependency on the part of all other foods. Bangladesh and Nepal have seen moderate to sharp increases in their import dependence of most food items.

Calculations on India's import dependence for total food show that the country met less than 1 per cent of its domestic food demand from abroad before WTO. During initial years of WTO this dependence increased to about 2 per cent (Table 7). In the post-WTO period pertaining to the years 1999 to 2002, there was a sharp decline in food self-sufficiency.

In the case of Nepal, the dependency on imports for food increased from 2.9 per cent in the pre-WTO period to 4.87 per cent in the post-WTO period. Food self-sufficiency in Bangladesh has suffered a sharp decline since 1995, and has met close to 18 per cent of its food requirement from imports in the recent years compared to 9.2 per cent in preWTO period.

Table 7

The dependence on import for food: aggregate

\begin{tabular}{lccc}
\hline Country & $1991-94$ & $1995-98$ & $1999-2002$ \\
\hline India & 0.89 & 2.02 & 3.76 \\
Pakistan & 8.46 & 8.12 & 7.45 \\
Bangladesh & 9.20 & 13.57 & 17.87 \\
Sri Lanka & 34.47 & 41.08 & 43.24 \\
Nepal & 2.89 & 2.93 & 4.87 \\
\hline
\end{tabular}

Notes: Aggregation based on weighted average of selected commodities using prices as weight; Imports exceeding domestic consumption, observed in the case of vegetable oil, are considered to constitute maximum domestic consumption.

Source: Calculated by author from the FAOSTAT Database. 
Sri Lanka was affected by low food self-sufficiency already in the pre-WTO period, as more than one-third of its food demands were met from imports. With the WTO-led trade liberalization, its dependence on imports accelerated further and is around 43 per cent. Pakistan, on the other hand, is the only nation among all SACs where food selfsufficiency has seen slight improvement since the beginning of WTO.

These results imply that if self-sufficiency is used as an indicator of food security, then with the progress of trade liberalization, food security has suffered a significant decrease in all SACs except Pakistan.

\subsection{Impact on self-reliance}

It is often asserted that trade liberalization promotes the allocation of resources based on comparative advantage. According to this logic, a country benefits, or improves its selfreliance, by specializing in the production of goods in which it has comparative advantage and imports items in which it does not have comparative advantage. This implies that trade liberalization provides opportunities to increase exports which can be used to finance imports. Based on this reasoning, two simple indicators of self-reliance are estimated. The first indicator is net trade, i.e., excess of exports over imports. This indicator is further refined by taking the ratio of net trade to GDP agriculture. The second indicator is taken as ratio of imports to exports to determine percentage of exports needed to finance imports.

The pattern of the two indicators of self-sufficiency discussed above can be seen from Table 8. Out of the five SACs, only India and Sri Lanka have positive net trade in agriculture whereas the other three countries have negative agricultural trade balance. Net earnings from agriculture increased in the case of India from 2.2 per cent of GDP agriculture in pre-WTO period to 2.90 per cent in the initial phase of WTO. In the postWTO period, the ratio of net trade in GDP declined to 1.28 per cent. Similarly, India spent only 43 per cent of its export earnings to finance imports during 1991-94. During 1999 to 2002, more than 72 per cent of export earnings were used for meeting agricultural imports. Thus, both the indicators of self-reliance reveal sharp decline in the post-WTO period.

Table 8

Self-reliance in agriculture,

measured as the ratio of net trade to GDP and the ratio of imports to exports

\begin{tabular}{llrrr}
\hline Country & Aspect & $1991-94$ & $1995-98$ & $1999-2002$ \\
\hline India & Net trade/GDP \% & 2.22 & 2.90 & 1.28 \\
\multirow{3}{*}{ Bangladesh } & Imports/exports \% & 43.31 & 48.78 & 72.72 \\
& Net trade/GDP \% & -6.26 & -11.70 & -12.47 \\
Nepal & Imports/exports \% & 517.99 & 900.64 & 1547.56 \\
& Net trade/GDP \% & -5.96 & -9.87 & -7.06 \\
Pakistan & Imports/exports \% & 288.16 & 452.76 & 332.65 \\
& Net trade/GDP \% & -4.38 & -7.68 & -5.00 \\
Sri Lanka & Imports/exports \% & 146.89 & 193.91 & 170.07 \\
& Net trade/GDP \% & 1.44 & 5.44 & 6.98 \\
\hline
\end{tabular}

Source: Calculated by author from the FAOSTAT Database and ADB (various issues). 
In the case of Bangladesh, agriculture imports exceeded exports and trade deficit was 6.46 per cent of GDP agriculture in the pre-WTO period. With the implementation of the WTO Agreement, this deficit increased to 11.7 per cent of GDP agriculture and has in recent years increased further. For comparison, the agricultural imports for Bangladesh were only five times its export during 1991-94. The value of imports has increased to more than 15 times the value of imports since the implementation of trade liberalization.

Nepal's and Pakistan's trade deficits have increased faster than GDP agriculture between the pre-WTO and the initial years of WTO. After 1998, the ratio of trade deficit to GDP declined somewhat but has remained higher than what it was in the pre-WTO period. Sri Lanka is the only country in South Asia that was able to improve its self-reliance in agriculture after WTO-related trade liberalization.

\subsection{Trade liberalization and agriculture growth}

Growth in GDP agriculture is an important and all encompassing indicator of the performance of the farming sector. Annual agricultural GDP growth rates for the different SACs during 1992 to 2003 are given in Figure 1. In order to give a better picture, the growth rates were computed from three yearly moving average series of GDP agriculture, as annual series showed considerable fluctuation. Growth rates are given as the per cent change over the previous year.

Figure 1

Agricultural GDP growth rates for selected SACs, 1992-2003
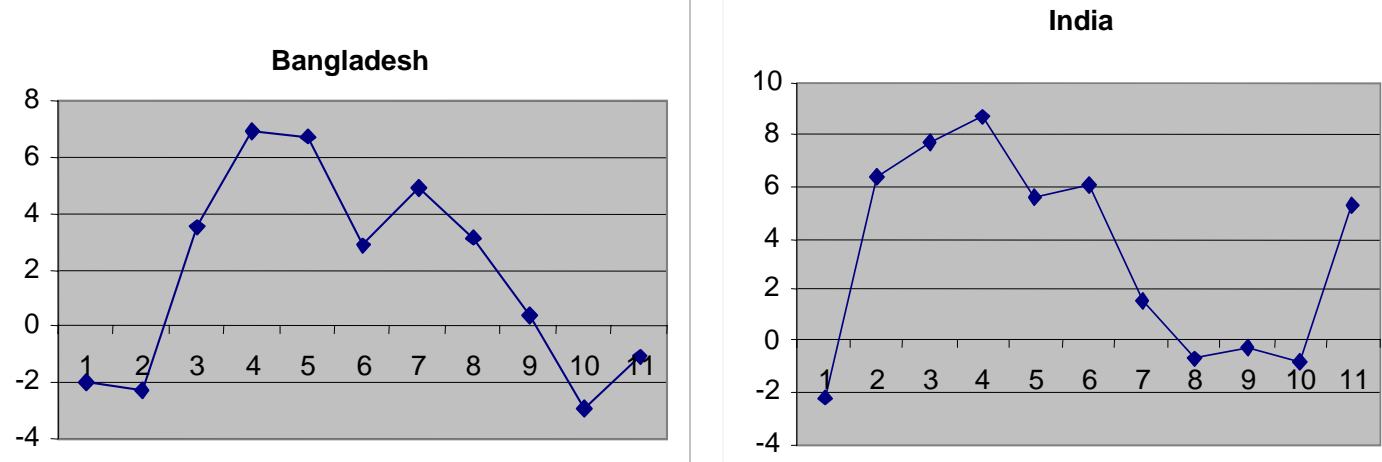

Nepal

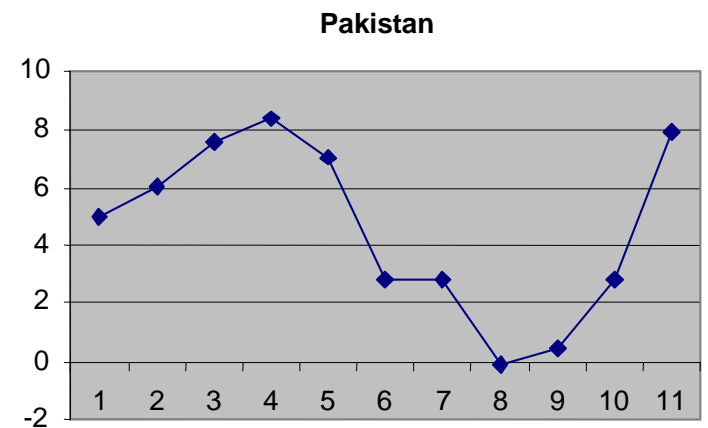

Figure 1 continues 


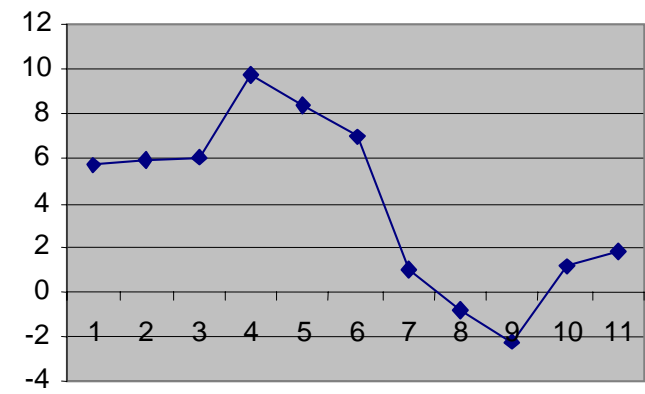

Source: Computed by author from the FAOSTAT Database.

As can be seen from Figure 1, the agriculture GDP growth rate shows a sharp deceleration in Bangladesh, India and Sri Lanka. In the case of Pakistan there was a deceleration with the beginning of WTO but growth rates have recovered in the postWTO period. Agriculture growth rate in Nepal remained unaffected by trade liberalization and WTO.

\section{Volatility in domestic and international prices}

International agricultural prices generally exhibit a cyclical pattern and are characterized by high volatility. A comparison of volatility in international prices and domestic prices in SACs for selected food products during 1991 to 2002 is shown in Table 9. Instability in international prices is higher than domestic prices in all SACs for all the selected commodities.

If international price shocks are transmitted to the domestic market, it would destabilize crop patterns and supply, and would cause uncertainty in crop incomes. Based on a comprehensive analysis of international and Indian prices in the last fifty years, Chand and Jha (2001) observe that government intervention has been quite effective in insulating domestic prices from effect of instability in international prices in developing countries like India. This implies that unregulated and free trade would impart

Table 9

Instability in domestic and international prices of selected food commodities

\begin{tabular}{lcccccc}
\hline Commodity & Bangladesh & India & Nepal & Pakistan & Sri Lanka & International \\
\hline Rice & 0.124 & 0.126 & 0.129 & & 0.099 & 0.145 \\
Maize & 0.122 & & 0.148 & & 0.177 \\
Wheat & & 0.064 & & 0.093 & & 0.163 \\
Groundnut & & 0.102 & & & 0.198 \\
Rapeseed & & 0.086 & & 0.181 & & 0.266 \\
Coconut & & 0.195 & & & 0.227 & 0.26 \\
\hline
\end{tabular}

Note: Instability in series, say $(\mathrm{Y})$, was measured as std dev. of $\left[\mathrm{Ln}\left(\mathrm{Y}_{\mathrm{t}+1} / \mathrm{Y}_{\mathrm{t}}\right)\right]$

Source: Calculated by author from the FAOSTAT Database. 
instability to domestic prices and there is strong case to regulate trade to maintain price stability. While domestic production must compete with the trend level of international prices, it must be protected against instability. One way to do so is to impose variable tariffs that restore level of current import prices to a long-term trend.

\section{Implementation of the Uruguay Round AoA and issues for negotiations}

Implementation of the Uruguay Round AoA has been a mixed blessing for SACs. It helped to create a favourable environment for trade reforms and for initiating trade liberalization, which were considered highly desirable for these countries. However, what was projected as the benefits from AoA for the SACs and expectations based on that did not come true.

\subsection{Domestic support}

Domestic policies in the SACs have been such that domestic prices of major agricultural produce were kept lower than global prices. This resulted in negative product-specific support or net taxation on agriculture. These countries provide some non-product specific support through subsidizing inputs like fertilizer, irrigation, power and credit supplied to agriculture. The magnitude of non-product specific support remained smaller compared to the negative product-specific support, which rendered the aggregate measure of support (AMS) negative for these countries. So far AMS in SACs remained within permissible, de minimus, level of support as per the UR AoA.

Agriculture in South Asia is in a transitional stage. Large segments are still underdeveloped and thus, in the initial stages, require considerable government assistance in order to harness its potential and for development. Huge investments are required in infrastructure and institutional development, as farmers are generally resource poor and do not have the capital to invest in agriculture. Markets are not well developed, and government intervention is needed to ensure a remunerative price environment that would lead to the adoption of improved technology. Therefore, SACs need provisions for product-specific as well as nonproduct-specific support for agriculture. Agriculture also has special needs that require assistance in the form of infrastructure development, research, extension, insurance, and market development. SACs need the Green Box subsidies for providing such assistance.

In a liberalized trade regime, competitiveness is affected by policies both on the domestic scene and the international scene. In this context it is important to see the various provisions of domestic support used by other countries. OECD countries particularly, EU members, USA, Canada, and Japan provide huge subsidies to their farmers in various forms that give their production an advantageous position vis a vis farmers in the developing countries. Moreover, Green and Blue Box subsidies have been used to compensate for any reduction in the Amber Box subsidy. This support enables developed-country farmers to reduce production costs and offer produce at lower prices, resulting in the developing countries being disadvantaged in exports and in competing with imports.

There is no justification for the developed countries to provide such support because their agricultural sector is highly commercialized and at an advanced stage of 
development. Infrastructure and markets are well developed and farmers are resourceful and capable of operating without government assistance. Therefore, in the new Agreement on Agriculture, the developed countries should disallowed from providing Amber or Blue Box support. Some well-defined measures could be considered under the Green Box option but their level should be capped to avoid misuse, as has been done in the past.

\subsection{Market access}

In the area of market access SACs have supported their commitments by (i) replacing nontariff border measures with tariffs, (ii) removing quantitative restrictions (QRs) and (iii) liberalizing their trade by lowering applied tariffs, even though these were below the bound rates, as can be seen from Table 10. Bangladesh bound its tariff on agricultural imports at 200 per cent with the exception of a few commodities with 150 and 50 per cent tariff. Against this, the average applied tariff has been maintained below 21 per cent, implying that tariff rates were brought down from 79.9 per cent and 53.5 per cent, respectively in 1989. India has mainly three bands of bound tariffs; 100-104 per cent for raw products such as cereals, most fruit and vegetables as well as oilseeds, pulses; 150 per cent for semiprocessed items (tea, chicken, wheat flour) and 300 per cent for processed products like vegetable oils, fats. There is some deviation from these broad norms for certain individual products. The simple mean and weighted average of applied tariffs on agricultural imports was 69.5 per cent during 1990; this was reduced to 28.2 per cent in 1998. Pakistan bound its agricultural import tariffs at 100 per cent for most products, but the bound tariff for wheat, sugar and tea was 150 per cent. Its applied tariffs during 1995, given as a simple mean and weighted mean were 46.3 and 24.0 per cent; currently tariff rates are 17.9 and 11.2 per cent. Sri Lanka was first among the SACs to initiate trade liberalization and progressively brought down its tariff rates even before WTO. Accordingly, it bound all its tariff rates at 50 per cent. Applied tariff rates were around 24 per cent during 1993, which have been reduced to 13.9 per cent on simple mean basis and 11.3 per cent on weighted mean basis.

Bound tariff in all SACs except Sri Lanka are very high on certain items. There is no justification to have bound tariffs above 100 per cent, as this would provide adequate protection even when international prices drop.

The liberalization of trade and the removal of QRs in the initial years of implementation of WTO agreement did not cause much difficulty because international prices of bulk products were quite high during the first three years. Subsequently, as international prices declined to a very low level and developed countries responded by granting huge subsidies to their producers, South Asian agriculture faced severe difficulties. Domestic production of staples also experienced the threat of disruption, and some countries resorted to desperate measures to deter cheap imports. This experience highlights the important lesson that due to the high volatility in international prices, the SACs are unable to safeguard domestic production against imports with the standard tariff measures if and when global prices drop to very low levels. In order to deal with similar situations, the SACs either need to bind their tariffs at very high levels so that applied tariffs can be raised appropriately, or, to initiate special safeguards to regulate imports of sensitive products. 
Table 10

Changes in tariff barriers on primary products in SACs with WTO

\begin{tabular}{lccc}
\hline Country & Year & Simple mean \% & Weighted mean \% \\
\hline Bangladesh & 1989 & 79.9 & 53.5 \\
& 1999 & 21.1 & 21.0 \\
\multirow{3}{*}{ India } & 2002 & 22.4 & 20.1 \\
& 1990 & 69.6 & 26.0 \\
& 1997 & 25.7 & 22.6 \\
Nepal & 2001 & 32.8 & 22.7 \\
& 1993 & 15.7 & 14.2 \\
& 1998 & 16.2 & 12.0 \\
Pakistan & 2002 & 16.0 & 8.3 \\
& 1995 & 46.3 & 24.0 \\
& 1998 & 42.7 & 26.2 \\
Sri Lanka & 2002 & 17.9 & 11.2 \\
& 1993 & 24.2 & 23.0 \\
& 1997 & 24.0 & 20.7 \\
& 2001 & 13.9 & 11.3 \\
\hline
\end{tabular}

Source: World Bank (various years).

Setbacks to exports occur because of poor or reduced access in other countries' markets. Developed countries have very high bound tariffs for selected products and they also have special safeguards to prevent the imports of certain products (WTO 2002). Some countries have variable tariffs, which rise in response to a fall in prices. All these measures reduce access to developed-country markets. If these measures fail, then at times sanitary and phytosanitary measures (SPS) are invoked without justification to check imports. Based on this experience, the strategy of the SACs should focus on seeking reasonable protection for their markets and greater access to developed-country markets.

\subsection{Export competition and subsidies}

The EU and USA, representatives of the major trading group, along with 23 other countries can subsidize exports. EU export subsidies in particularly have caused concern to the developing countries. Among SACs, Pakistan occasionally resorts to freight subsidies on fruit and vegetables, or undertakes state trading for cotton and rice. At times, concession is provided on export credit (Khan 2003). Sri Lanka provides limited subsidies for some agricultural exports and duty concessions for exporters on the import of capital goods. The Sri Lanka Export Credit Insurance Corporation provides export insurance and guarantee service for the development of exports (Kelegama 2003). India provides income tax exemptions on profits from agricultural exports, as well as domestic and international freight subsidies for some exported commodities. Bangladesh also extends assistance to agricultural exports in the form of concessional interest rates and export credit guarantee. SACs provide only indirect support on some agricultural exports on some agricultural exports permitted within the UR AoA. These do not parallel the direct export subsidies provided by the industrialized countries (Gulati 2003).

Among the SACs, there is no deviating from the issue of export subsidies. These countries should make a strong plea for immediate and complete elimination of export 
subsidies as these are highly trade distorting. Due to underdeveloped infrastructure, markets and trade institutions in the SACs, government intervention at times in terms of measures to provide freight subsidy, incur certain marketing costs or promote export incentives during initial stages become essential to in order to develop export potential. SACs need to seek exemption in these as a part of their special and differential (S\&D) treatment.

\subsection{State trading enterprises}

State trading enterprises (STEs) have played an important role in all SACs in creating a remunerative price environment for producers that has resulted in output growth, commercialized promotion of agricultural trade and an improvement in food security. The main functions of a STE include price administration, procurement and the sale of a significant part of domestic production, the maintenance of commodity stock, and monopoly in imports and exports. Some STE functions are considered trade-distorting, while most are of regulatory and promotional nature.

There has been considerable change in the role of STEs and their importance in the recent past. Bangladesh has considerably diminished the role of the Bangladesh Food and Allied Corporation, Trading Corporation of Bangladesh and other parastatals during the 1990s, but the country maintains a national foodstock under the public foodgrain distribution system. In Pakistan, an increasing number of the functions of PASCO are being commercialized and STEs like Rice Export Corporation, Cotton Export Corporation and Trading Corporation of Pakistan are operating on a commercial principle. Sri Lanka has couple of STEs in the food sector. The Cooperative Wholesale Establishment (CWE) is the major STE entrusted with the task of price stabilization and food security. CWE undertakes the bulk purchase of agriculture commodities and imports wheat with exclusive trading right. Market intervention role of CWE and other STE has diminished over time (Kelegama 2003). The Food Corporation of India (FCI) plays a predominant role in price administration of wheat and paddy/rice through bulk purchases of marketed surplus at predetermined price, the maintenance of large stocks and the release of stock for public distribution, for the open market and, of late, for exports. FCI has the cereal-import monopoly; this was partly lifted in 1999 and shortly re-instated after cheap imports glutted India's coastal areas despite adequate stocks in government warehouses. India has virtually eliminated the function of several other STEs in the imports and exports of vegetable oil, cotton, sugar, etc.

In the long run, it is in the interests of SACs to reduce the role of STEs and to promote private enterprise in agricultural marketing and trade. However, the global market is unreliable for meeting the food-security concerns of the low-income populations of South Asia because of price volatility, the strong hold of commodity cartels over global trade, and the international market's limited capacity to absorb major supply-and-demand shocks. Therefore the SACs need the state trading enterprises address food-security concerns, particularly of weaker sections of society. But these STEs should play minimalist role, and should operate without either domestic or international trade monopolies along with private trade. 


\section{Summing up}

The policy of trade liberalization as followed by the SACs, particularly since implementation of the WTO Agreement in 1995, has considerably increased their dependence on imports for meeting food requirements. All SACs, with the exception of Sri Lanka, indicate a deterioration in agricultural self-reliance in the post-WTO period. The deterioration is a reflection of the much higher growth in food imports than in the growth in agricultural exports because domestic production of the SACs, even after high tariffs, cannot compete with cheap imports. Furthermore, their exports faced stiff competition in global markets. The underlying reason for both developments was unexpectedly low level of international prices.

The subsidies in OECD countries have a major impact on the level of international prices and market distortions. Thus, the SACs need to adopt an agenda that leads to a reduction in production subsidies, and in support and export subsidies, as all of these cause distortions and low prices on the global markets. This would eliminate the possibility of import threats for several products, and prospects for exports could improve.

One of the reasons for deceleration in agriculture growth in SACs is the deterioration in agricultural terms of trade resulting from low international prices. SACs need to safeguard their farmers against price shocks that can have adverse impact on production. This can be done with special safeguards to check large-scale imports of cheap goods.

Trade has an important role in food security, as it offers the possibility to stabilize domestic prices, to balance food deficiency, and to harness comparative advantage. In fact, satisfying a small fraction of demand through trade can have a positive impact on improving the efficiency of domestic production and thus should not be seen as a threat to domestic producers. However, domestic capacity for food production should be not stifled by the dependence on trade. The SACs need to strike a balance between food self-sufficiency and trade, by carefully evaluating the diverging crop production across countries.

Per capita income in SACs is quite low and more than half of household expenditure is spent on food. A vast majority of the population is not able to absorb volatility and shocks in the international markets. Therefore, these countries need to pursue food self-sufficiency, particularly for main staples, to maintain food security until such a time that the per capita incomes increase. This necessitates that domestic capacity in food production be strengthened and developed further in an efficient manner so that the domestic produce is competitive with normal international prices. 


\section{References}

Asian Development Bank (ADB) (various issues). Key Indicators of Developing Asian and Pacific Countries. Manila: ADB

Chand, R. (2002). WTO, Trade Liberalization and Indian Agriculture. New Delhi: Mittal Publications.

Chand, R., and D. Jha (2001). 'Trade Liberalization, Agricultural Prices and Social Welfare', in S. S Acharya and D. P. Chaudhri (eds), Indian Agricultural Policy at the Crossroads. Jaipur: Rawat Publications, 17-126.

Dowlah, C. A. F. (2003). 'Bangladesh', in M. D. Ingco (ed.), Agriculture, Trade and WTO in South Asia. Washington, DC: World Bank.

Gulati, A. (2003). 'India', in M. D. Ingco (ed.), Agriculture, Trade and WTO in South Asia. Washington, DC: World Bank.

Kelegama, S. (2003). 'Sri Lanka', in M. D. Ingco (ed.), Agriculture, Trade and WTO in South Asia. Washington, DC: World Bank.

Khan, S. (2003). 'Pakistan', in M. D. Ingco (ed.), Agriculture, Trade and WTO in South Asia. Washington, DC: World Bank.

Panagariya, A. (2003). 'Trade Liberalization and Food Security: Conceptual Links', in Trade Reforms and Food Security. Rome: FAO, 25-42

World Bank (various years). World Development Indicators. Washington, DC: World Bank.

World Trade Organization (WTO) (2002). 'Special Agriculture Safeguard’. Background Paper by the Secretariat. G/AG/NG/S/9/Rev.1. Rome: WTO. 